\title{
Eco-friendly dyeing of cellulosic fabric using Direct Red 28 and Direct Blue 15 dyes
}

\author{
Rehman F.-U. ${ }^{1}$, Adeel S. ${ }^{2 *}$, Akmal M. ${ }^{1}$, Majeed K. ${ }^{1}$, Iqbal S.Z. ${ }^{1}$ and Amin N. ${ }^{1}$ \\ ${ }^{1}$ Department of Applied Chemistry, Govt. College University, Faisalabad 38000, Pakistan \\ 2Department of Chemistry, Govt. College University, Faisalabad 38000, Pakistan \\ Received: 30/06/2019, Accepted: 09/12/2019, Available online: 27/05/2020 \\ *to whom all correspondence should be addressed: e-mail: shahidadeel@gcuf.edu.pk \\ https://doi.org/10.30955/gnj.003176
}

\section{Graphical abstract}

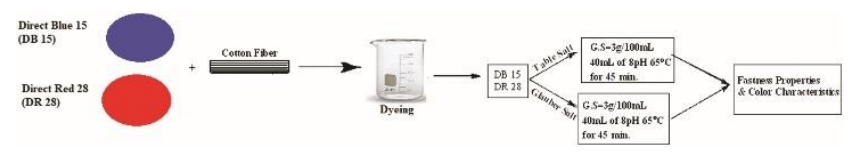

\section{Abstract}

Sustainability in textiles is now a day's key demand of consumers and traders, where the process with zero effluent emission or less emission has been considered for aim to utilize the ecofriendly process in direct dyeing of cotton to minimize effluent load. For this purpose, variable amount of Table salt and Glauber salt has been used to achieve maximum exhaustion during direct cotton dyeing. Different dyeing variables have been employed; shade made at the optimum conditions were assessed according to ISO standards. It has been found that $3 \mathrm{~g} / 100 \mathrm{~mL}$ of table salt for Direct dyeing of cotton using $40 \mathrm{~mL}$ of DR $28(8 \mathrm{pH})$ at $65{ }^{\circ} \mathrm{C}$ for $45 \mathrm{~min}$, whereas using $40 \mathrm{~mL}$ of DB $15(8 \mathrm{pH})$ for dyeing of cotton at $65{ }^{\circ} \mathrm{C}$ for 45 min containing $3 \mathrm{~g} / 100$ $\mathrm{mL}$ of Glauber slat has given acceptable color characteristics. The reduction in dyeing variable using low salt amount has proved that this method is cost, time and energy efficient process, which can be utilized for dyeing of natural fabrics using various classes of dyes to obtain sustainable textile products.

Keywords: Cotton, colorfastness, Direct Red 28, Direct Blue 15 , Glauber salt, sustainability, table salt.

\section{Introduction}

Textile industry is the economic hub of global community (Zhou et al., 2017). Textile and apparel industry usually rely on synthetic dyes for production of finished goods. Due to brighter and sharper shades of synthetic dyes, they appeal human nature deeply (Tawfik and Rehan, 2018). According to a comprehensive research, about $7 \times 10^{8} \mathrm{Kg}$ per annum synthetic dyes are manufactured worldwide. Synthetic dyes are required to meet the human demands off sharp and beautiful colors in the field of textiles, increased awareness of environmental issues demands methods to be adopted to reduce effluent load and to attain higher rate of fixation adequate amounts of salts are used (Rosa et al., 2019; Kim et al., 2019). Dyes are classified on the basis of color, structure and mode of application. Depending upon the mode of application of dyes, Acid dyes, Basic dyes, Disperse dyes, Reactive dyes, Sulfur dyes, vat dyes and direct dyes are widely available. Among all the dyes Direct dyes have their own importance. For the production of clothing at local level, Direct dyes are mainly favored due to their comparatively low cost, minimal energy consumption, water solubility fine light fastness, comparable in application, shorter dye cycle, low cost of auxiliaries, remarkably lesser use of water and much lower salt level in effluent (Deshuai et al., 2017). After treatments of fabric dyed with Direct dyes yield better fastness properties. Direct dyes is anionic class of dyes having good attraction for cellulosic and protein fibres. Direct dyes include chemically different groups the most common ones are azo, anthraquinone and phthalocyanine dyes (Yusra and Nawaz, 2010). Textile industry today mainly favors dyeing of cellulosic and protenous family like cotton, yarn and silk etc. Apparel industry uses cotton fibres the most about $50 \%$.

Certain auxiliaries are used to make dyeing process smooth and effective. Most important auxiliary used in direct dyes is concentration of electrolyte. Salts are important auxiliary as it lowers zeta potential, exhaustion of dye is directly proportional to concentration of electrolyte and it tends to absorb dye molecules on fabric (Debasree et al., 2018). Usually sodium salts are used as an electrolyte in dyeing because of their low cost and easy availability. In present study our focus is on the influence of Table salt ( $\mathrm{NaCl})$ TS and Glauber's salt $\left(\mathrm{Na}_{2} \mathrm{SO}_{4}\right) \mathrm{GS}$ in direct dyeing of cotton using Direct Blue 15 and Direct Red 28. As both these salts $(\mathrm{NaCl}) \mathrm{TS}$ and $\left(\mathrm{Na}_{2} \mathrm{SO}_{4}\right) \mathrm{GS}$ are water soluble and produce sodium ions their effect is almost same except the anion produced (Burkinshaw and Salihu, 2019a). In case of Table salt chloride ions cause corrosion of dyeing medium. On the other hand sulfate ions of Glauber salt cause repulsion between negatively charged sulphonic groups of dye. 


\section{Materials and method}

\subsection{Sample preparation}

Direct Red 28 (DR 28; C.I 22120) and Direct Blue 15 (DB 15; C.I 24400) dye was provided by Paragon Dyes \& chemicals Faisalabad Pakistan and other chemicals such as $\mathrm{NaCl}, \mathrm{HCl}$, $\mathrm{Na}_{2} \mathrm{SO}_{4}{ }^{\circ}, \mathrm{Na}_{2} \mathrm{CO}_{3}$, neutral soap and wetting agent etc. used were of local grade(Pak Made) were used in this study were produced from by Pakistan scientific store (Pvt. Ltd.), Faisalabad, Pakistan). Mil treated plain cotton fabric was obtained from Noor Fatima Fabric Faisalabad, Pakistan.
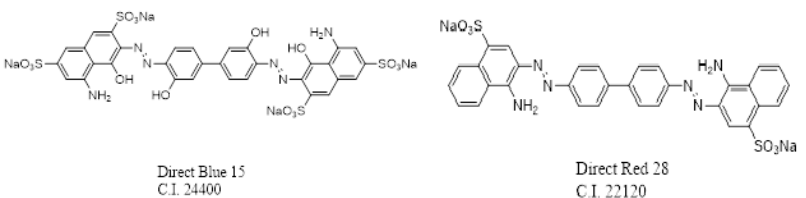

\subsection{Dyeing process}

\subsubsection{Effect of salt on direct dyeing}

Using two dyes effect of salt Table salt ( $\mathrm{NaCl}$; T.S) and Glauber salt (GS; $\mathrm{Na}_{2} \mathrm{SO}_{4}$ ) were observed. For the purpose of table salt was added $1 \mathrm{~g} / 100 \mathrm{ml}$ during dyeing of cotton with DR 28 dye keeping dye solution to cotton fabric ratio $1: 25$ at $60{ }^{\circ} \mathrm{C}$ for $60 \mathrm{~min}$ (Tarikul et al., 2017). Same process was repeated using DB 15 solution. After dyeing, hot \& cold water washing was given to dyed fabric three times, dried \& subjected to spectra flash for K/s \& Lab values. All the process done was same except for both dyes that the concentration of table salt $(\mathrm{NaCl})$ were $2,3,4,5$ $\mathrm{g} / 100 \mathrm{ml}$ instead of $1 \mathrm{~g} / 100 \mathrm{ml}$ for making comparison 1-5 $\mathrm{g} / 100 \mathrm{ml}$ of Glauber salt $\left(\mathrm{Na}_{2} \mathrm{SO}_{4}\right)$ was used as exhausting agent for both dyes (Burkinshaw and Salihu, 2019; Paul et al., 2017).

\subsubsection{Effect of temperature on direct dyeing}

Temperature of dye bath was optimized by dyeing $1 \mathrm{~g}$ of fabric using DB 15 containing $3 \mathrm{~g} / 100 \mathrm{ml}$ of table salt ( $\mathrm{NaCl}$ ) \& Glauber salt $\left(\mathrm{Na}_{2} \mathrm{SO}_{4}\right)$ keeping dye liquor to fabric ratio $1: 25$ at $35^{\circ} \mathrm{C}$. All the process of dyeing was same except the heating level was $45^{\circ} \mathrm{C}, 55^{\circ} \mathrm{C}, 65^{\circ} \mathrm{C}, 75^{\circ} \mathrm{C}, 85^{\circ} \mathrm{C}$ instead of $35^{\circ} \mathrm{C}$. To observe the role of $\mathrm{NaCl}$ (TS) and $\left(\mathrm{Na}_{2} \mathrm{SO}_{4}\right) \mathrm{GS}$ on dyeing the fabric $(1 \mathrm{~g})$ was dyed with DR 28 containing 3 $\mathrm{g} / 100 \mathrm{ml}$ of $\mathrm{GS}$ at $35^{\circ} \mathrm{C}$. All the process of dyeing was same except the heating level was $45^{\circ} \mathrm{C}, 55^{\circ} \mathrm{C}, 65^{\circ} \mathrm{C}, 75^{\circ} \mathrm{C}, 85$ ${ }^{\circ} \mathrm{C}$ instead of $35^{\circ} \mathrm{C}$.

\subsubsection{Effect of dyeing period on direct dyeing}

Contact time is optimized by dyeing $1 \mathrm{~g}$ of fabric using DR 28 dye containing $3 \mathrm{~g} / 100 \mathrm{ml}$ of $(\mathrm{NaCl}) \mathrm{TS}$ and $\left(\mathrm{Na}_{2} \mathrm{SO}_{4}\right) \mathrm{GS}$ at $65{ }^{\circ} \mathrm{C}$ keeping dye liquor to fabric ratio $1: 25$. All the process of dyeing was same except the contact period was $30,45,60 \mathrm{~min}$ instead of $15 \mathrm{~min}$. To optimize the dyeing period using DB 15, $1 \mathrm{~g}$ of fabric was dyed using $3 \mathrm{~g} / 100 \mathrm{ml}$ $(\mathrm{NaCl}) \mathrm{TS}$ and $\left(\mathrm{Na}_{2} \mathrm{SO}_{4}\right) \mathrm{GS}$ at $65{ }^{\circ} \mathrm{C}$ for $15 \mathrm{~min}$. All the process of dyeing was same except the contact period was kept 30, 45, 60 min instead of $15 \mathrm{~min}$.

\subsubsection{Effect of $\mathrm{pH}$ on direct dyeing}

$\mathrm{pH}$ of dye bath is optimized using DB15, $1 \mathrm{~g}$ of fabric was dyed for 45 mins using $(\mathrm{NaCl}) \mathrm{TS}$ and $\left(\mathrm{Na}_{2} \mathrm{SO}_{4}\right) \mathrm{GS}$ at $65{ }^{\circ} \mathrm{C}$ keeping liquor to fabric ratio 1:25 keeping $\mathrm{pH}$ of dye bath
5. Similarly, all the process was done keeping all conditions were same except $\mathrm{pH}$ of dye bath was $6,7,8,9,10,11$ instead of $5 \mathrm{pH}$. Moreover, optimization of $\mathrm{pH}$ is done using DR 28 by dyeing $1 \mathrm{~g}$ of cotton fabric for 45 min using ( $\mathrm{NaCl}$ ) TS and $\left(\mathrm{Na}_{2} \mathrm{SO}_{4}\right) \mathrm{GS}$ at $65{ }^{\circ} \mathrm{C}$ keeping liquor to fabric ratio 1:25 maintaining dye bath at $\mathrm{pH} 5$. All the process was repeated same except $\mathrm{pH}$ of dye bath was $6,7,8,9,10,11$ instead of $5 \mathrm{pH}$.

\subsubsection{Effect of volume on direct dyeing}

Volume of dye bath was optimized by employing $10 \mathrm{ml}$ of DR 28 for $1 \mathrm{~g}$ of cotton containing $3 \mathrm{~g} / 100 \mathrm{ml}$ of $(\mathrm{NaCl}) \mathrm{TS}$ and $\left(\mathrm{Na}_{2} \mathrm{SO}_{4}\right) \mathrm{GS}$ at $65{ }^{\circ} \mathrm{C}$ for $45 \mathrm{~min}$ keeping $\mathrm{pH}$ of dye bath at $9 \mathrm{pH}$. Similarly, all dyeing conditions were kept same using 20,30,40,50, $60 \mathrm{ml}$ of dye volume instead $10 \mathrm{ml}$. In another series of experiments $10 \mathrm{ml}$ of DB15 was employed for $1 \mathrm{~g}$ of fabric containing $3 \mathrm{~g} / 100 \mathrm{ml}$ of TS $(\mathrm{NaCl})$ and $\mathrm{GS}\left(\mathrm{Na}_{2} \mathrm{SO}_{4}\right)$ at $65^{\circ} \mathrm{C}$ for 45 mins at $\mathrm{pH} 9$ (Haque, 2015). Similarly, all dyeing process was same using 20, 30, $40,50,60 \mathrm{ml}$ of dye volume instead $10 \mathrm{ml}$.
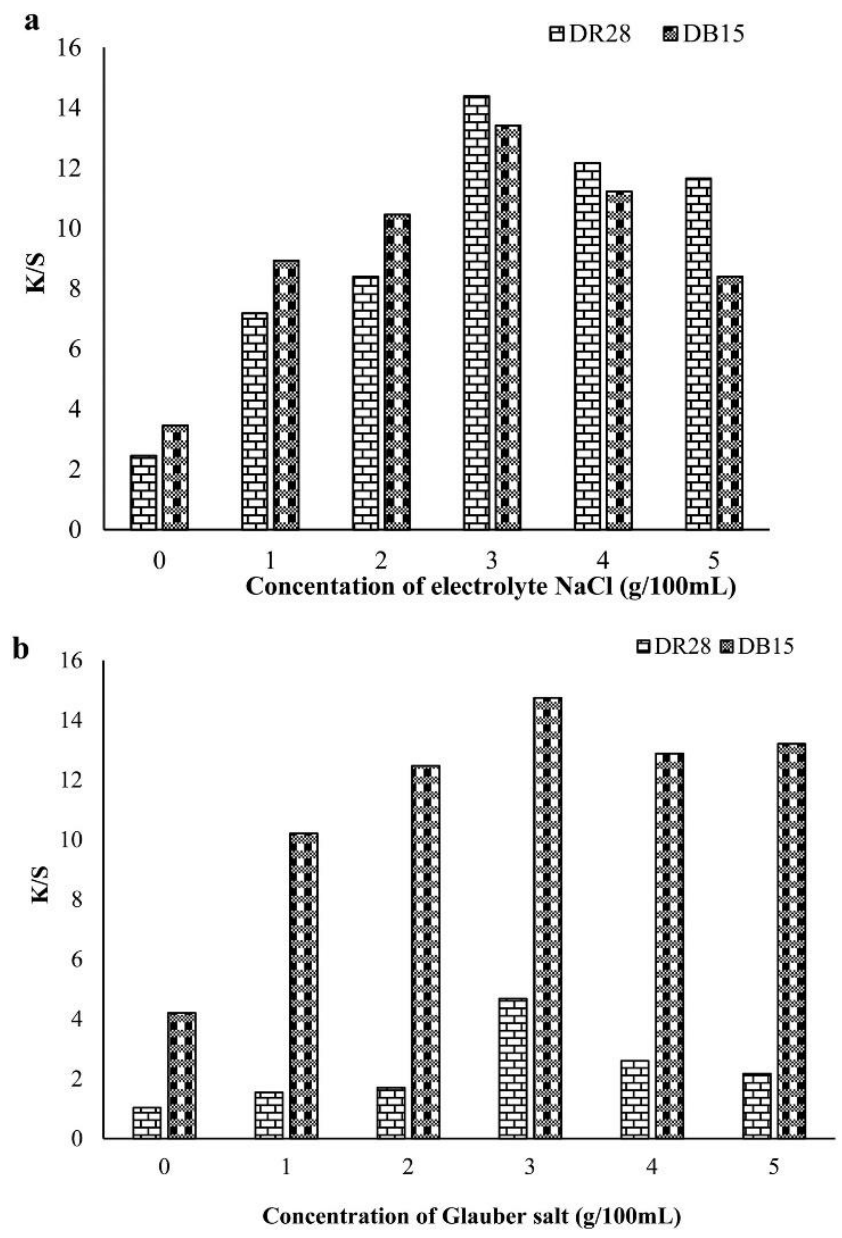

Figure 1. a. Effect of Table salt on dyeing of cellulosic fabric with Direct Red (DR)28 and Direct Blue (DB)15 dye. b. Effect of Glauber salt on dyeing of cellulosic fabric with Direct Red (DR)28 and Direct Blue (DB)15 dye

\subsection{Analysis of undyed fabric \& dyed fabric}

The change in characteristic peak of fabric before and after dyed fabric was taken through Fourier-transform infrared spectroscopy FTIR. For color strength value of all dyed fabric were assessed in specter flash (SF 600), at 
Department of Applied Chemistry Government Collage University Faisalabad, Pakistan. The color fastness properties of the dyed fabric at optimum conditions were rated at grey scale using standard method of ISO.
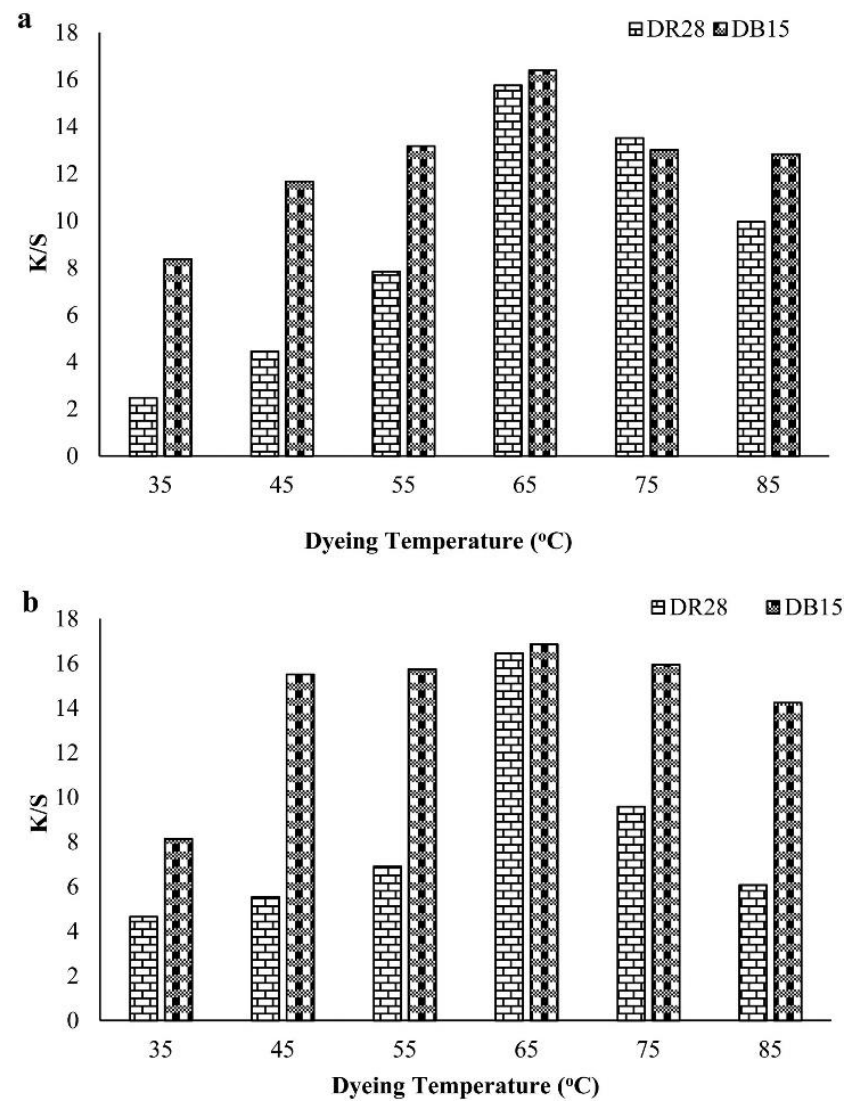

Figure 2. a. Effect of Table salt on heating for dyeing of cotton using Direct Red (DR)28 and Direct Blue (DB) 15 dye. b. Effect of Glauber salt on heating for dyeing of cotton using Direct Red (DR)28 and Direct Blue (DB)15 dye

\section{Results and discussion}

\subsection{Effect of salt}

It is found that direct dyes are used to dye cellulosic fibres initially their sub stativity towards less without presence of salt (Samera Salimpour Abkenar et al., 2015). This is because when fabric is immersed in solution it gets negative charge due to which it repels molecules and upon dyeing low fixation is observed in presence of salt this negative charge on the fabric may be neutralized by adding salt to facilitate the dye for form interaction within range of short attractive force (Tarikul et al., 2017). Thus addition of salt results in excellent exhaustion which yields good color strength. The results given in (Figure 1a) revels that using $3 \mathrm{~g} / 100 \mathrm{ml}$ table salt using DB 15 and DR 28 has exhausted dye bath well there by yielding excellent color strength. Low amount of salt doesn't evolve the color from dye bath to move towards fabric, whereas to much high amount may promote over exhaustion due to which sudden aggregation dye molecule may results in poor proper fixation which upon washing the unfixed colorant molecules ate washed at low shade is observed. The brightness of shades using Glauber's salt has been changed due to larger extent of repulsion between sulphate ions of dye and electrolyte (Burkinshaw and Salihu, 2019). The result given in (Figure 1 b) revels that using $3 \mathrm{~g} / 100 \mathrm{ml}$ glauber salt produced good color strength on cotton fabric.

\subsection{Effect of temperature}

Direct dyeing of cotton is always temperature dependent because only a certain heating level accelerate dye bath kinetics with gradual rise of heating, the molecules become activate only up to certain level gain high kinetic energy to sorb onto fabric (Grande et al., 2017). But after certain level, the rate of dyeing which is present in equilibrium with rate of decomposition become recessive for low tint (Bhatti et al., 2014; Batool et al., 2011). The results given in (Figure 2a) reveal that dyeing of cotton at $65^{\circ} \mathrm{C}$ has given excellent results using TS $(3 \mathrm{~g} / 100 \mathrm{ml})$ as exhausting agent using DR 28 and DB15. By application of Glauber's salt, it refers changing in brightness of shades because the nature of the salt has taken molecules towards fabric through different way. It is noticed that using DR 28 and DB 15 using GS $3 \mathrm{~g} / 100 \mathrm{ml}$ as electrolyte showed excellent result at $65^{\circ} \mathrm{C}$ (Debasree et al., 2017). The results are given in Figure $2 \mathrm{~b}$.
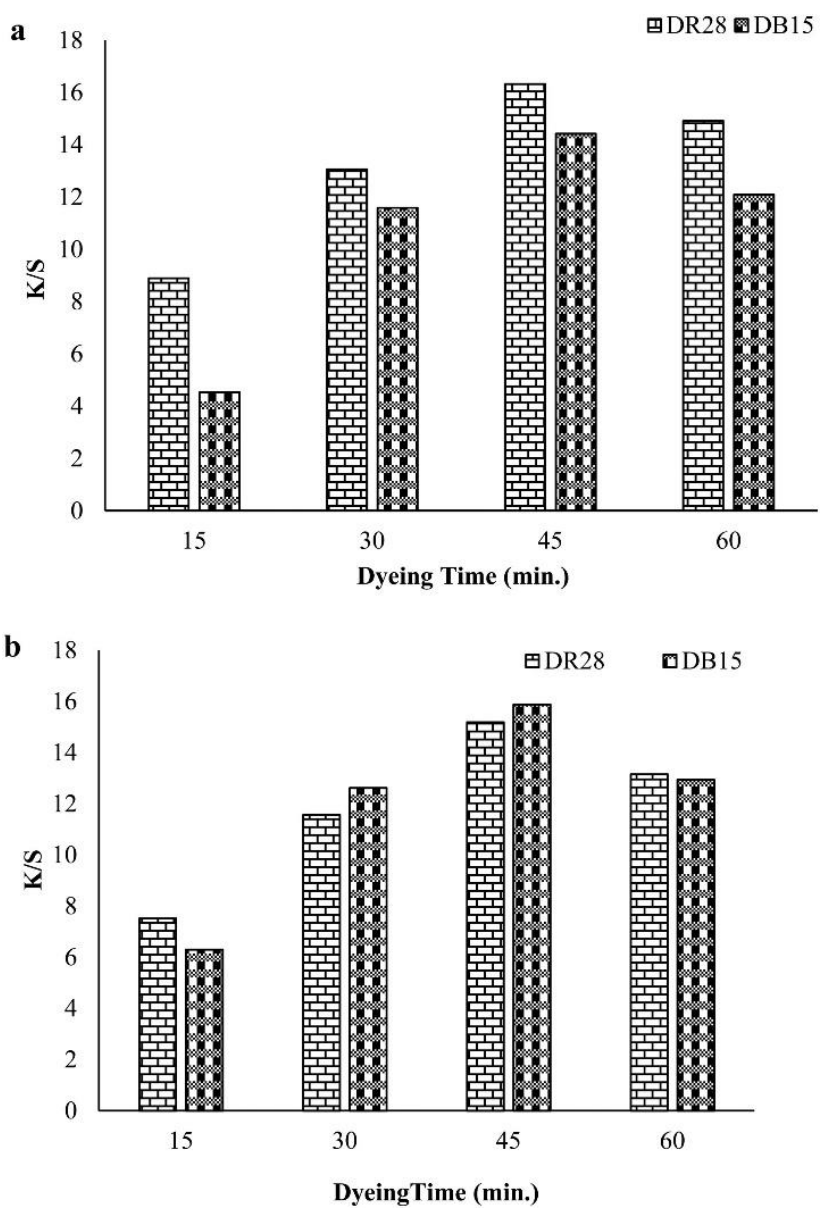

Figure 3. a. Effect of Table salt on contact level for dyeing of cotton using Direct Red (DR)28 and Direct Blue (DB)15 dye. b. Effect of Glauber salt on heating for dyeing of cotton using Direct Red (DR)28 and Direct Blue (DB)15 dye 


\subsection{Effect of time}

The rate of direct dyeing is always prone to some levels particularly time and temperature. Heating for short time does not activates the dye molecules to rush towards the fabric, whereas for long time heating the molecules may start removing from fabric to dye bath due to rise in rate of desorption instead of dyeing (Hauq et al., 2014). Hence dyeing for optimum level is recommended to get desired results. The data displayed in (Figure 3a) using Table salt and (Figure 3b) using Glauber's salt reveal that dyeing of cotton for 45 minutes has given excellent results using DB15 and DR 28. Dyeing for low time produces low tint (Amato et al., 2018). Whereas dyeing for much higher time also produces low tint due to desorption process of dye (Adeel et al., 2017).
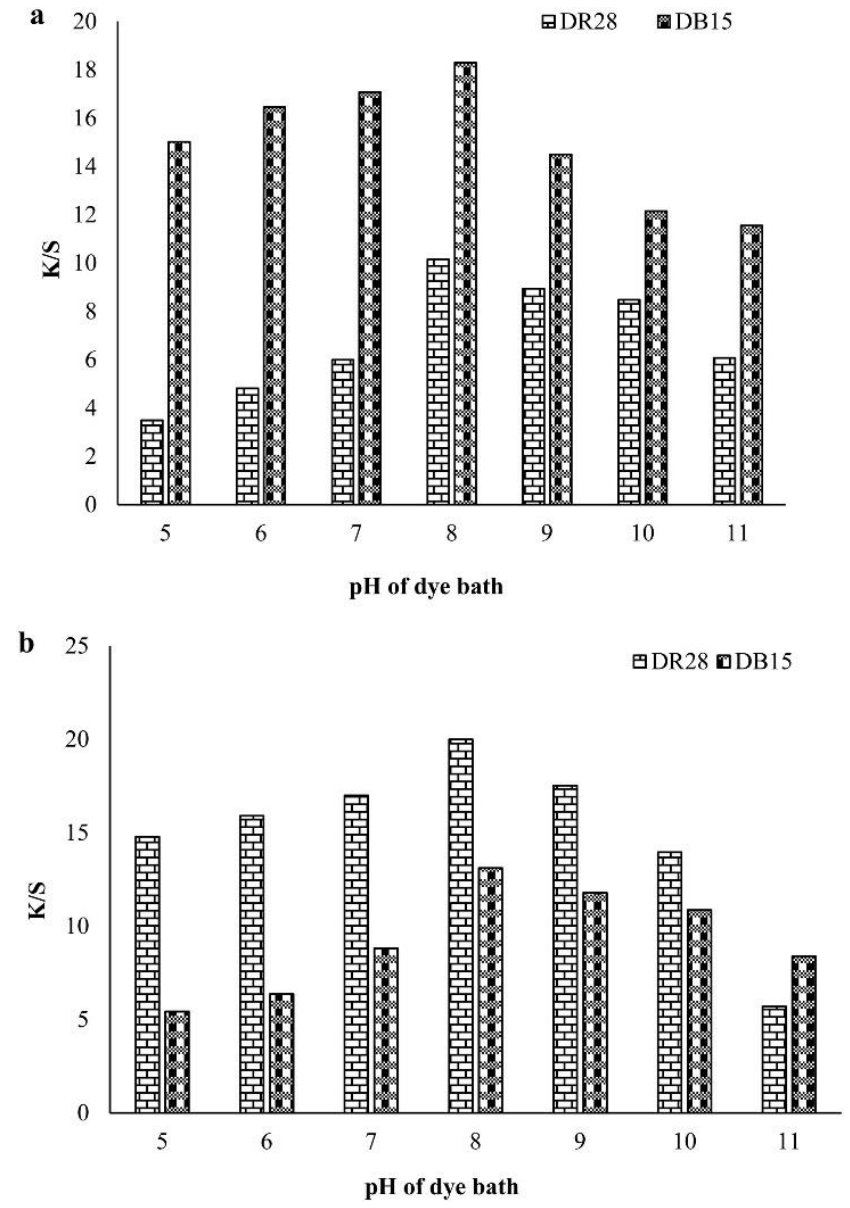

Figure 4. a. Effect of dye bath $\mathrm{pH}$ on dyeing of cellulosic fabric with Direct Red (DR)28 and Direct Blue (DB)15 dye using Table salt. b. Effect of dye bath $\mathrm{pH}$ on dyeing of cellulosic fabric with Direct Red (DR)28 and Direct Blue (DB)15 dye using Glauber salt

\subsection{Effect of $\mathrm{pH}$}

Dye uptake ability of fabric like cotton is remarkably influenced by $\mathrm{pH}$ of dyeing medium in dyeing bath. Fabric immersed in water acquires negative charge, moreover, dye molecules in solution also have negatively charged groups, so there is repulsion between both fabric and dye molecules. $\mathrm{pH}$ of dye bath and electrolyte bot affects in such a way that there increasing concentrations lowers the repulsion between fabric and dye molecular anions by developing opposite charge on dye molecules, hence improves dye-ability. But too much high $\mathrm{pH}$ of medium cause greater repulsion between high concentration of hydroxide ions of alkaline medium and $-\mathrm{OH}$ ions of fabric (Sun et al., 2017; Ngulube et al., 2017). From (Figure 4a) using Table salt and (Figure 4b) using Glauber's salt, excellent color strength is given at $\mathrm{pH}$ 9. It is concluded that appearance of shades improves greatly by increasing $\mathrm{pH}$ of dyeing medium. But very high value $\mathrm{pH}$ of alkaline medium cause significant increase in repulsion between anions of dye and cellulose.

\subsection{Effect of dye volume}

The salt effect is always prominent on the direct dyeing of cotton using DR28. The utilization of salt for exhaustion of particular volume to get desired result depending upon nature of dye, it's made of action table salt used has taken $40 \mathrm{ml}$ of dye for maximum exhaustion towards fabric (Burkinshaw and Salihu, 2019b). Low value does not cause sorption of dye to much extent due low context, whenever to much volume of dye bath accumulation of dye molecules at greater extent in the form of aggregates. Then aggregates found much difficulty in sorption of fabric (Irfan et al., 2018). The data given in (Figure 5a) using Table salt and (Figure 5b) using Glauber's salt reveals that dyeing of cotton gives excellent results using $40 \mathrm{ml}$ solution of $1 \%$ solution of DB15 and DR 28.
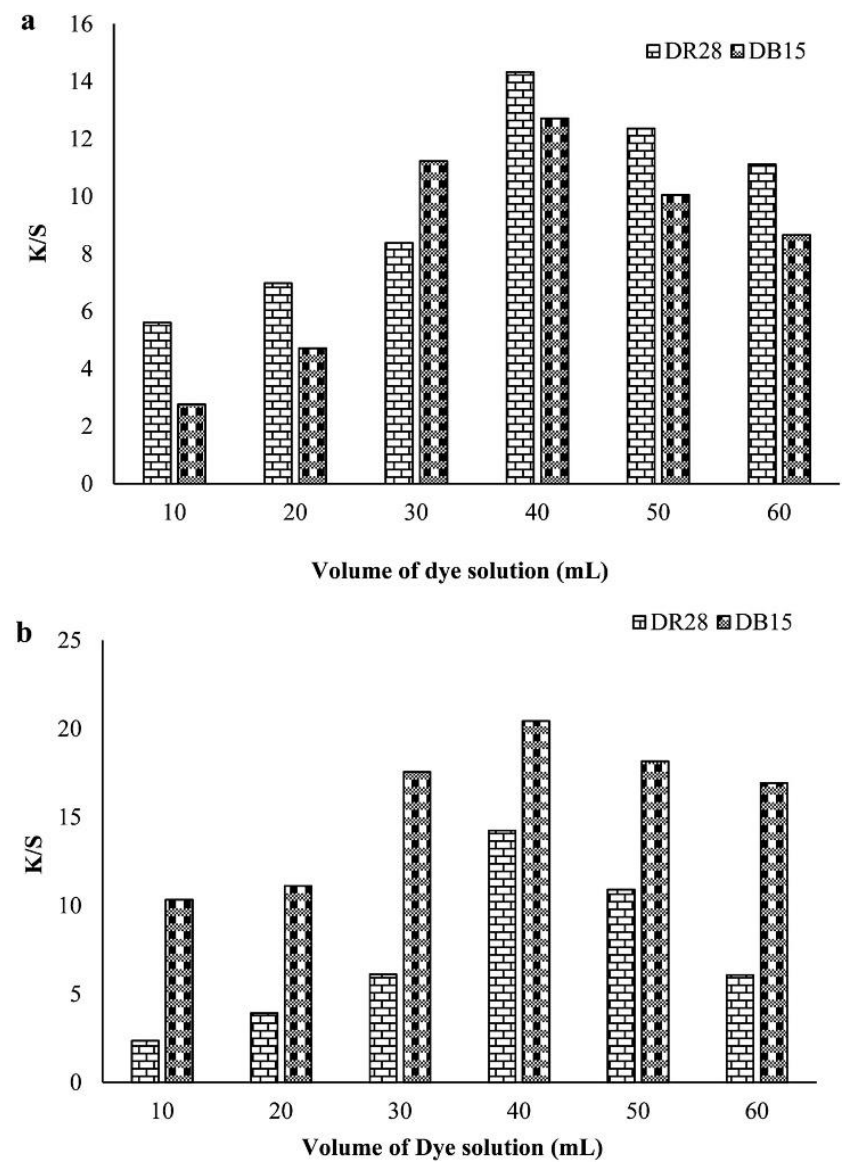

Figure 5. a. Effect of volume of dye bath on dyeing of cellulosic fabric with Direct Red (DR)28 and Direct Blue (DB)15 dye using Table salt. b. Effect of volume of dye bath on dyeing of cellulosic fabric with Direct Red (DR)28 and Direct Blue (DB)15 dye using Glauber salt 


\subsection{Fastness properties}

The rating results given in Table 1 (a) for shades using Direct Red 28 DR 28 dye and Table 1(b) for shades using Direct Blue 15 DB 15 dye, reveal that Table salt TS and Glauber salt GS utilization to achieve maximum exhaustion at given dyeing conditions have been improved. Good light, wash and rubbing fastness can be attributed to the presence of conjugation systems, benzenoid rings, auxochromes and the mode of bonding (ljaz et al., 2014; Adeel et al., 2015).
The cellulosic fabric always shows good resistance after leveling dyeing with Direct Red 28 and Direct Blue 15, because big dye molecules may find good penetration, there by firm fixation yield good shade. Similarly, colorfastness to perspiration and dry cleaning also affected by molecular size, dyeing process, nature of fabric as well as presence of auxiliaries during dyeing (Kiran et al., 2019). Hence all this fastness jointly adds value in coloration of fabric using Direct Red 28 and Direct Blue 15 at optimal conditions and examine colorfastness characteristics.

Table 1. (a) Rating of fastness properties of dye fabric using Direct Red 28 dye. (b) Rating of fastness properties of dye fabric using Direct Blue 15 dye

\begin{tabular}{|c|c|c|c|c|c|c|c|c|c|c|c|c|c|c|}
\hline \multirow[t]{3}{*}{ Shades } & \multicolumn{7}{|c|}{$\mathrm{NaCl}$} & \multicolumn{7}{|c|}{$\mathrm{Na}_{2} \mathrm{SO}_{4}$} \\
\hline & \multirow[t]{2}{*}{ LF } & \multicolumn{2}{|c|}{ WF } & \multicolumn{2}{|c|}{ RF } & \multirow[t]{2}{*}{ DCF } & \multirow[t]{2}{*}{ PF } & \multirow[t]{2}{*}{ LF } & \multicolumn{2}{|c|}{ WF } & \multicolumn{2}{|c|}{ RF } & \multirow[t]{2}{*}{ DCF } & \multirow[t]{2}{*}{ PF } \\
\hline & & C.C & C.S & DRF & WR(F & & & & C.C & C.S & DRF & WRF & & \\
\hline \multicolumn{15}{|l|}{ (a) } \\
\hline 1 & 4 & 4 & $3 / 4$ & $4 / 5$ & $4 / 5$ & $4 / 5$ & $4 / 5$ & 5 & 4 & $3 / 4$ & $4 / 5$ & $4 / 5$ & $4 / 5$ & $4 / 5$ \\
\hline 2 & $4 / 5$ & 4 & $3 / 4$ & $4 / 5$ & 4 & 4 & $4 / 5$ & 5 & $4 / 5$ & 4 & 5 & $4 / 5$ & $4 / 5$ & $4 / 5$ \\
\hline 3 & $4 / 5$ & 4 & $3 / 4$ & $4 / 5$ & 4 & 4 & $4 / 5$ & 5 & $4 / 5$ & 4 & 5 & $4 / 5$ & $4 / 5$ & $4 / 5$ \\
\hline 4 & $4 / 5$ & 4 & $3 / 4$ & $4 / 5$ & 4 & 4 & $4 / 5$ & 5 & 4 & $3 / 4$ & $4 / 5$ & $4 / 5$ & $4 / 5$ & $4 / 5$ \\
\hline 5 & $4 / 5$ & 4 & $3 / 4$ & $4 / 5$ & 4 & 4 & $4 / 5$ & 5 & 4 & $3 / 4$ & $4 / 5$ & $4 / 5$ & $4 / 5$ & $4 / 5$ \\
\hline \multirow[t]{3}{*}{ Shades } & \multicolumn{7}{|c|}{$\mathrm{NaCl}$} & \multicolumn{7}{|c|}{$\mathrm{Na}_{2} \mathrm{SO}_{4}$} \\
\hline & \multirow[t]{2}{*}{ LF } & \multicolumn{2}{|c|}{ WF } & \multicolumn{2}{|c|}{ RF } & \multirow[t]{2}{*}{ DCF } & \multirow[t]{2}{*}{$\mathrm{PF}$} & \multirow[t]{2}{*}{ LF } & \multicolumn{2}{|c|}{ WF } & \multicolumn{2}{|c|}{ RF } & \multirow[t]{2}{*}{ DCF } & \multirow[t]{2}{*}{ PF } \\
\hline & & C.C & C.S & DRF & WRF & & & & C.C & C.S & DRF & WRF & & \\
\hline \multicolumn{15}{|l|}{ (b) } \\
\hline 1 & 4 & $3 / 4$ & $3 / 4$ & 4 & $3 / 4$ & $4 / 5$ & $4 / 5$ & $4 / 5$ & 4 & $3 / 4$ & $4 / 5$ & 4 & 4 & $4 / 5$ \\
\hline 2 & 4 & $3 / 4$ & $3 / 4$ & 4 & $3 / 4$ & 4 & $4 / 5$ & 5 & $4 / 5$ & 4 & 5 & $4 / 5$ & 4 & $4 / 5$ \\
\hline 3 & $4 / 5$ & $3 / 4$ & 4 & 4 & $3 / 4$ & 4 & $4 / 5$ & 5 & $4 / 5$ & 4 & 5 & $4 / 5$ & $4 / 5$ & $4 / 5$ \\
\hline 4 & $4 / 5$ & $3 / 4$ & 4 & 4 & $3 / 4$ & 4 & $4 / 5$ & 5 & $4 / 5$ & 4 & $4 / 5$ & 4 & $4 / 5$ & $4 / 5$ \\
\hline 5 & $4 / 5$ & $3 / 4$ & 4 & 4 & $3 / 4$ & 4 & $4 / 5$ & 5 & $4 / 5$ & 4 & $4 / 5$ & 4 & $4 / 5$ & $4 / 5$ \\
\hline
\end{tabular}

LF $=$ Light Fastness, WF = Wash fastness, DRF \& WRF = Dry \& Wet wash fastness, DCF = Dry clean fastness, PF = Perspiration fastness

\section{Conclusion}

The global community due to spread awareness of sustainability is following such processes and products which are green and clean with low effluent load as well as cost, time and energy effective. In this study method employed has shown excellent results onto cellulosic fabric Direct Red 28 and Direct Blue 15 dyes, where the utilization of low salts has exhausted colorant molecules to much extent towards fabric there by reducing levels of dyeing variables. This study concluded that by employing this method not only coloration of natural fabrics using other classes of dyes can be made ecofriendly for global community, but also acceptable color characteristics can be achieved.

\section{References}

Adeel S., Kiran S., Gulzar T., Rehman F., Azeem M., Ahmad Z., Zuber M., Kamran M. and Iqbal Z. (2017), Influence of ultrasonic radiation on the dyeing of cotton fabric using reactive yellow 145 Dye, Journal of Natural Fibers, 14(5), 658665.

Adeel S., Usman M., Haider W., Saeed M., Muneer M. and Ali M. (2015), Dyeing of gamma irradiated cotton using direct yellow 12 and Direct Yellow 27, improvement in colour strength and fastness properties, Cellulose, 22, 2095-2105.
Batool I., Bhatti I.A., Adeel S. and Abbas M. (2011), Effect of gamma radiations on dyeing of cotton fabric with Reactive Blue 13, Research Journal of Textile and Apparel, 15(3), 107-114.

Bhatti I.A., Adeel S., Siddique S. and Abbas M. (2014), Effect of UV radiations on dyeing of cotton fabric with reactive blue 13 , Journal of Saudi Chemical Society, 18(5), 606-609.

Burkinshaw S.M. and Salihu G. (2019a), The role of auxiliaries in the immersion dyeing of textile fibres: Part 4 theoretical model to describe the role of liquor ratio in dyeing cellulosic fibres with direct dyes in the absence and presence of inorganic electrolyte, Dyes and Pigments, 161, 565-580.

Burkinshaw S.M. and Salihu G. (2019b), The role of auxiliaries in the immersion dyeing of textile fibres: Part 5 practical aspects of the role of inorganic electrolytes in dyeing cellulosic fibres with direct dyes, Dyes and Pigments, 161, 581-594.

Grande G.A., Giansetti M., Pezzin A., Rovero G. and Sicardi S. (2017), Use of the ultrasonic cavitation in wool dyeing process: effect of the dye-bath temperature, Ultrasonics Sonochemistry, 35, 276-284.

Haque A.N.M.A. (2014), Effect of dyeing parameters on dyeing of cotton fabrics with fluoro chloro pyrimidine reaction dyes, International Journal of Research in Engineering and Technology, 3(4), 125-128. 
Irfan M., Zhang H., Syed U. and Hou A. (2018), Low liquor dyeing of cotton fabric with reactive dye by an eco-friendly technique, Journal of Cleaner Production, 197, 1480-1487.

Kim T., Seo B., Park G. and Lee Y.W. (2019), Effects of dye particle size and dissolution rate on the overall dye uptake in supercritical dyeing process, The Journal of Supercritical Fluids, 151, 1-25.

Kiran S., Adeel S., Rehman F.U., Gulzar T., Jannat M. and Zuber M. (2019), Ecofriendly dyeing of microwave treated cotton fabric using reactive violet H3R, Global Nest Journal, 21, 43-47.

Ngulube T., Gumbo J.R., Masindi V. and Maity A. (2017), An update on synthetic dyes adsorption onto clay-based minerals: a state-of-art review, Journal of environmental management, 191, 35-57.

Paul D., Das S.C., Islam T., Siddiquee M.A.B. and Al M.A. (2017), Effect of alkali concentration on dyeing cotton knitted fabrics with reactive dyes, Journal of Scientific and Engineering Research, 4(12), 388-393.

Rosa J.M., Garcia V.S., Boiani N.F., Melo C.G., Pereira M.C. and Borrely S.I. (2019). Toxicity and environmental impacts approached in the dyeing of polyamide, polyester and cotton knits, Journal of Environmental Chemical Engineering, 7(2), 123.

Sun D., Zhang X., Du H., Fang L. and Jiang P. (2017), Application of liquid organic salt to cotton dyeing process with reactive dyes, Fibers and Polymers, 18(10), 1969-1974.

Tawfik A.K. and Rehan M. (2018), A Review on synthesis of nitrogen-containing heterocyclic dyes for textile fibers - part 1: five and six-membered heterocycles, Egyptian Journal of Chemistry, 61, 897-937.

Yusra S. and Bhatti H.N. (2010), Factors affecting biosorption of direct dyes from aqueous solution, Asian Journal of Chemistry, 22(9), 6625-6639.

Zhou L., Xu K., Cheng X., Xu Y. and Jia Q. (2017), Study on optimizing production scheduling for water-saving in textile dyeing industry, Journal of cleaner production, 141, 721-727. 